\title{
Tulane
}

Tulane Economics Working Paper Series

\section{Progressivity of Pricing at U.S. Public Universities}

\author{
Emily E. Cook \\ Sarah Turner \\ Tulane University \\ ecook4@tulane.edu \\ University of Virginia and \\ NBER \\ sturner@virginia.edu
}

Working Paper 2103
January 2021

\begin{abstract}
Substantial increases in public university tuition often raise concerns about college affordability. But assessment of the impacts on low- and moderate-income families requires consideration of whether net tuition - tuition less grant aid - has increased commensurately. This paper describes recent shifts in net tuition by family income and institution type and assesses the role of changes in state funding in generating these shifts. Using data reported by universities on net tuition paid by students from different family income levels, we find that public research universities have increasingly shifted to high-tuition, high-aid pricing. From 2012 to 2017, net tuition fell by far more than would have been predicted by the growth in state appropriations, while tuition levels continued to rise, albeit at a slower rate than in the prior years. The increased progressivity in pricing, particularly among research universities, cannot be explained by changes in state appropriations.
\end{abstract}

Keywords: Tuition, Public universities, Student financial aid JEL codes: I23; I2; H7 


\title{
Progressivity of Pricing at U.S. Public Universities
}

\author{
Emily E. Cook \\ Tulane University
}

Sarah Turner

University of Virginia and NBER

\begin{abstract}
Substantial increases in public university tuition often raise concerns about college affordability. But assessment of the impacts on low- and moderate-income families requires consideration of whether net tuition - tuition less grant aid - has increased commensurately. This paper describes recent shifts in net tuition by family income and institution type and assesses the role of changes in state funding in generating these shifts. Using data reported by universities on net tuition paid by students from different family income levels, we find that public research universities have increasingly shifted to high-tuition, high-aid pricing. From 2012 to 2017, net tuition fell by far more than would have been predicted by the growth in state appropriations, while tuition levels continued to rise, albeit at a slower rate than in the prior years. The increased progressivity in pricing, particularly among research universities, cannot be explained by changes in state appropriations.
\end{abstract}

Keywords: tuition, public universities, student financial aid

JEL Codes: I23; I2; H7

Emily E. Cook: Corresponding author. Tulane University Department of Economics. 302 Tilton Hall, 6823 St. Charles Avenue, New Orleans, LA 70118. Email: ecook4@tulane.edu.

Sarah Turner: University of Virginia and NBER. 244 Monroe Hall, Charlottesville, Virginia, 22903. Email: sturner@virginia.edu.

Declarations of interest: none 


\section{Progressivity of Pricing at U.S. Public Universities}

\section{Section 0. Introduction}

Rising tuition at public universities has brought renewed attention to the questions of "who pays" and "who benefits" from U.S. public higher education. Enrollment-weighted average tuition at four-year public universities increased by approximately $200 \%$ between academic years $1987-88$ and 2017-18, with increases particularly marked in the years around the Great Recession and then slowing in recent years. ${ }^{1}$ Because about $70 \%$ of students at four-year universities in the U.S. attend a public university, the potential burden of increased prices is consequential.

But headline comparisons of tuition charges at public universities do not capture the distribution of prices paid by students from different circumstances. Indeed, the net tuition paid by students from the lowest-income families (less than $\$ 30,000$ in family income) at four-year universities increased by only $0.3 \%$ between $2008-09$ and $2017-18$, while tuition increased by $38.1 \%$. The affordability and progressivity of higher education depend upon the distribution of grant aid by income and institution type. For the 2017-18 academic year, tuition net of grant aid for students with family incomes under $\$ 30,000$ was lower at flagship universities (generally regarded as the most selective in the state) than at non-research universities in 36 states, even as tuition is typically higher at flagship universities. ${ }^{2}$ As Hansen and Weisbrod (1969) identified 50 years ago, high tuition combined with high aid may be more progressive than low (or zero) tuition.

With data on net tuition paid by family income for in-state students, we measure the "passthrough" rate of tuition changes by family income within each institution. In essence, for each dollar increase in posted tuition, how does net tuition change for students from low- and moderate-income families? Net tuition paid by students with family incomes under $\$ 30,000$ increases with tuition at a rate of 29 cents per dollar at Carnegie R1 ("very high research activity") institutions, 84 cents per

\footnotetext{
${ }^{1}$ Unless otherwise noted, statistics in the text and figures are from the authors' calculations based on data from the National Center for Education Statistics' (NCES) Integrated Postsecondary Education Data System (IPEDS). ${ }^{2}$ Appendix Figure 1 illustrates these differences across income ranges for in-state, first-time, full-time students. Throughout this paper we use "tuition" to mean tuition and fees and "net tuition" to mean tuition and fees minus grants and aid that do not have to be repaid. Net tuition may be negative if students receive grants and aid that cover tuition, fees, and some portion of room and board.
} 
dollar at non-research institutions, and 92 cents per dollar at community colleges. ${ }^{3}$ In effect, research universities appear to engage in more price discrimination by family circumstances than do 2-year and non-research 4-year institutions.

Descriptive evidence aligning net tuition and tuition changes likely confounds multiple factors affecting tuition, including budget shocks and demand shocks. Changes in state appropriations are an especially policy-relevant budget shock that may impact tuition and, in turn, net tuition paid by students from different circumstances. While it has been well-established that tuition increases less than dollar-for-dollar with declines in appropriations per student (Bound et al., 2019; Deming and Walters, 2017; Chakrabarti, Gorton, and Lovenheim, 2020), this analysis is the first to examine the response of net tuition at different income levels to changes in appropriations. In general, appropriations changes do not explain increased progressivity of pricing by family income. To organize evidence, we decompose the changes in tuition levels and net tuition into those attributable to state appropriations and other residual factors, including demand-side adjustments in the market. Residual factors beyond changes in state appropriations appear as the most significant force in shaping the progressivity of pricing. We hypothesize that, for research universities, changes in market demand combined with increasingly diversified revenue streams facilitated the shift to high tuition, high-aid pricing, resulting in reductions in net tuition for students with financial need in recent years.

Recent pricing trends are unambiguously more generous for low-income students only if aid increases are coupled with steady or increasing low-income enrollment. We find that changes in lowincome enrollment shares in connection with tuition increases are statistically indistinguishable from zero at non-research universities. R1 universities see gains in the representation of low-income students when tuition increases, even as it remains the case that low-income students are relatively underrepresented at these institutions.

\footnotetext{
${ }^{3}$ In some cases, we separate out flagship universities, which are often the most resource-intensive in each state. For most of the analysis we employ the Carnegie Classification (2010) taxonomy to distinguish institutions into broad categories based on degrees awarded and research intensity (Carnegie Foundation, 2011). We focus on three aggregates: R1, (those with very high research activity in Carnegie (2010)), R2 and doctoral (high research activity and doctoral universities), and non-research, which includes the remaining four-year degree granting colleges and universities. While there is variation within categories, the R 1 universities tend to be the most selective with the highest levels of expenditures per student.
} 
Our analysis proceeds with a brief overview of the key institutional details related to tuition setting and grant-based aid at U.S. public universities. The second section turns to the outline of the empirical strategy and data. The third section presents the results, and the final section concludes.

Section 1. Pricing Public Higher Education - Background Evidence

Tuition setting in public higher education represents a combination of political economy factors and market incentives. In the U.S., the provision of higher education occurs through a decentralized and mixed market of private and state-controlled public institutions. State systems of public higher education are stratified—in some cases by design— by selectivity, resources, and pricing, with this stratification increasing over time (Courant, McPherson, and Resch, 2006). In general, public universities have different in-state and out-of-state tuition rates, with the lower "instate" rate reflecting a subsidy for in-state students. The reduced in-state rate is supported (historically) by state appropriations.

Grant aid produces an additional source of variation in prices paid by students, placing the net tuition paid by students appreciably below the posted tuition level and the average cost of instructional services. Thus, pricing at public universities depends on both posted tuition and the distribution of grant aid. The last two decades have produced marked increases in the level of tuition charged to in-state students, along with the availability of grant aid. What is more, there has been a striking increase in stratification: the most research-intensive universities (which tend to have the greatest level of resources) have increased both tuition levels and grant aid the most. We set out these pricing characteristics below.

\section{Measuring Grant Aid and Net Tuition Charged}

A panel of tuition charges at individual universities has been maintained for several decades by the Department of Education, but trends in net tuition levels by family circumstances are historically hard to find. The challenge is that verified family income is required (given that student self-reports are likely to be error-ridden), along with data on all sources of grant aid (not just a single source like Pell grants). Our primary data source is a relatively recent addition to the IPEDS surveys, 
the "Student Financial Aid and Net Price" module. ${ }^{4}$ Beginning with the 2008-09 academic year, this module records net tuition and average grants and aid by income group for first-time, full-time, instate students (at public universities, all students at private institutions) who receive Title IV financial aid. Students who complete the FAFSA and receive either federal grants or loans make up the universe of Title IV recipients.

Figure 1 summarizes these data for public universities and brings together two critical points of this paper. Between 2007-08 and 2017-18, tuition has risen more at research institutions than at non-research institutions. As shown in the figure, net tuition has fallen for students in all but the highest income bin $(\$ 110 \mathrm{k}+)$ at public AAU universities (members of the Association of American Universities, generally regarded as some of the most elite, high-resource institutions in the country). Even as tuition and fees increased by about $\$ 2,900(30 \%)$ at the AAU universities, net tuition for the lowest income groups fell (- $\$ 470$ for the $\$ 0-\$ 30 \mathrm{k}$ income group and $-\$ 2,560$ for the $\$ 48-\$ 75 \mathrm{k}$ income group). At non-research public universities and community colleges, tuition increases were somewhat smaller, as were the gains in grant aid and concurrent reductions in net tuition.

This presentation motivates our analysis of the correspondence among the rising tuition at public colleges and universities, the increased stratification in tuition charges between institutions, and the growth in price discrimination by family income within research universities. In the next section, we consider the tuition-grant aid nexus for public universities in the context of prior research and basic economic theory before turning to empirical analysis.

\footnotetext{
${ }^{4}$ The data present some challenges. For example, the data record family income in nominal categories, which could produce compositional changes in the relative income of families in each bin. This is not a significant problem because inflation was low during our period of observation between 2008-09 and 2017-18. Selection presents another potential problem, as we only observe data for student who applied for aid. However, we do not think this is a significant issue for students from families making \$75k or less. Public data from the NCES' National Postsecondary Student Aid Study generally support this. In both the 2008 and 2016 NPSAS surveys, first-time, full-year, bachelor's-degree-seeking students at four-year public universities in family income brackets below $\$ 75,000$ applied for federal aid at rates exceeding $82 \%$ for every income group. Application for aid has increased substantially over time for students in higher income groups (on the order of 15 percentage points), so estimates for these groups reflect a greater degree of selection.
} 
Figure 1: Net Tuition by Income and Institution Type, 2008 and 2017
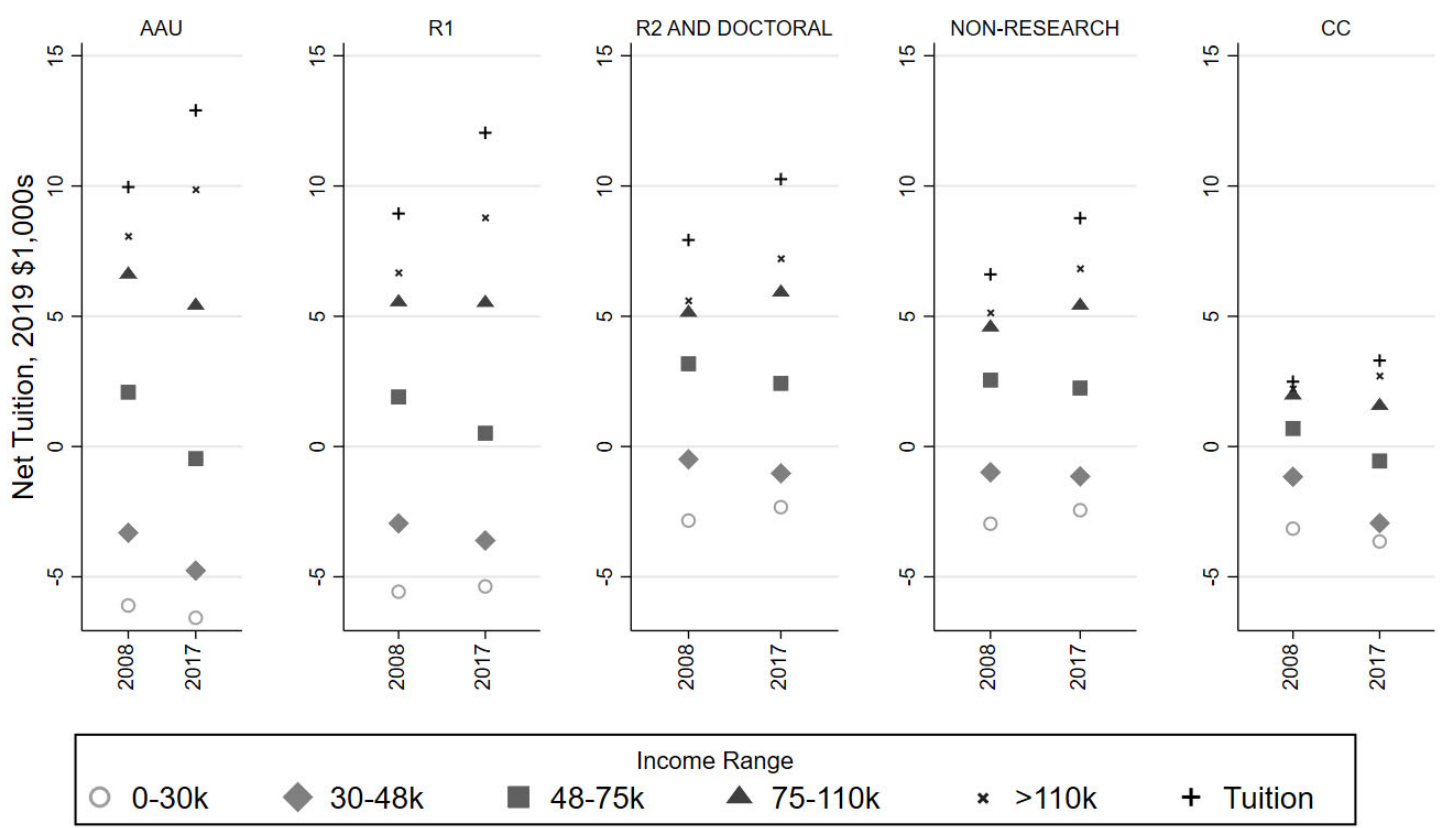

Note: This figure shows net tuition (tuition and fees minus average grants and aid) by income group in 2008 and 2017 for in-state, full-time, first-time students. Net tuition can be negative because grant aid may exceed tuition and fees to cover a portion of room and board. The figure includes five groups of public institutions: members of the Association of American Universities (AAU), the universities classified as R1, R2 and doctoral, or nonresearch in the Carnegie Classification System, and 2-year institutions. AAU universities are a subset of R1; the other categories are mutually exclusive.

\section{Section 2. Understanding the Tuition-Grant Aid Nexus for Public Universities}

Consideration of the university budget constraint in the context of university objectives guides understanding of the determinants of tuition and financial aid at public universities. A public university's revenues include tuition revenues, state appropriations, private gifts, and grants. Tuition revenues are a function of the relative quantities of in-state and out-of-state students, along with the prices charged to each group. On the other side of the budget equation are expenses. In this exposition, we focus on instructional expenditures and institutional grant aid. The former purchases educational resources such as faculty, while the latter effectively purchases specific student characteristics (e.g., merit aid is used to attract students with higher academic performance, while need-based aid may attract more low-income students). Researchers often model a university's 
objective function with student characteristics and instructional resources as inputs (see, for example, Bound et al., 2019 and Epple et al., 2019). ${ }^{5}$

If instructional inputs and student aid are complementary in the university's objective, exogenous negative revenue shocks result in reductions in both instructional inputs and student aid. The demand system will dictate the corresponding changes in tuition levels. State appropriations, which are one piece of the revenue side of the budget constraint, likely include some variation that is independent of university actions (Bound et al., 2019). This paper directly examines the effects of appropriations on tuition and net tuition while recognizing that appropriations changes are just one of many factors impacting public universities' pricing decisions. Demand-side factors, including changing demand among students from abroad, likely impact revenue streams and institutional choices (Bound et al., 2020), while universities also respond to other shifting revenue sources and competitive pressures within the U.S. market. Modeling all the margins of adjustment that could contribute to the patterns observed in Figure 1 requires the specification of a demand system and a fuller articulation of the optimization problem, which is beyond the scope of this analysis. Our focus is on understanding the role of changes in state appropriations, as changes in appropriations levels are among the most salient and policy-relevant shocks to universities' budget constraints since 2008 .

\section{The Role of State Appropriations and Tuition Charges}

In 2001-02, appropriations per student hit a peak near $\$ 10,000$ per student, but in the years immediately following the Great Recession appropriations took a significant hit, dropping to $\$ 6,830$ per student. The period of our study begins with academic year 2008-09 and ends with 2017-18. During this time, constant-dollar appropriations first fell from $\$ 8,980$ to $\$ 6,830$ between academic years 2008-09 and 2011-12, then recovered slowly through academic year 2017-18 to reach $\$ 7,986$ (SHEEO, 2020).

\footnotetext{
${ }^{5}$ Rothschild and White $(1993,1995)$ motivate the allocation of grant aid in the context of models in which students with different characteristics vary in their importance in a university's objective function or in their contribution to peer learning. Epple et al. (2019) explore price discrimination in higher education in the context of a general equilibrium model in which universities extract rents from high demand students and, in turn, provide subsidies to other students that meet particular institutional needs.
} 
Several recent empirical papers explore how public institutions and student outcomes adjust to appropriations. There is increasing consensus that state appropriations impact educational outcomes, including degree attainment and time to degree through the channel of instructional expenditures (Deming and Walters, 2017; Chakrabarti, Gorton, and Lovenheim, 2020). Other research has shown that appropriations changes induce additional adjustments, such as changes in the composition of students to attract more full-pay students from abroad (Bound et al., 2020). These studies also demonstrate significant price effects, with decreasing state appropriations placing upward pressure on tuition levels. Nonetheless, public universities differ in the extent to which they can change the mix of enrolled students (to include more full-pay out-of-state students, for example). The nature of demand may impact how appropriations declines are accommodated in relation to increases in-state tuition, reductions in expenditures or shifts in the composition of students.

\section{Grant Aid, Tuition and Net Tuition}

Grant-based aid varies in its source — federal, state, or institutional — and the criteria for distribution, generally "need" and/or "merit." By construction, the difference between posted tuition and net tuition is grant aid. Both the state governments and the federal government play an active and substantial role in disseminating grant-based aid. The most extensive single program is the federal Pell grant, which provides grant aid to low-income students that is "portable," meaning that students can use these funds to attend any institution. The program had nearly $\$ 29$ billion in funding in 20172018. The constant dollar (2019) maximum federal Pell increased markedly from $\$ 5,518$ to $\$ 6,374$ between 2008-09 and 2009-10, with the real value eroding slightly to \$6,205 in 2018-19 (Ma et al., 2020). States also offer grant aid to students, totaling about $\$ 12.4$ billion in the $2017-18$ academic year. Individual states differ in the magnitude of such support and the division in allocation between "need" and "merit" (NASSGAP, 2019). Institutional grant-based aid is awarded based on both need and merit (which includes academic and athletic scholarships) and, in 2017-18, totaled $\$ 52$ billion in awards to undergraduate students (Ma et al., 2020).

The allocation of need-based financial aid follows from a standardized assessment of student and parent capacity to pay (Expected Family Contribution, EFC): the total cost of attendance (tuition plus a room and board allowance) minus EFC is "need." Universities vary in the extent to which they 
can meet need with institutional grant aid. ${ }^{6}$ Institutional grant aid is "last dollar" in the sense that it is applied after state and federal grants. Thus, when an institution raises tuition it increases need dollarfor-dollar for student who already qualify for aid, while also increasing the number of students with need at the extensive margin.

How universities adjust their own pricing decisions — in both tuition setting and the allocation of institutional grant aid - to state and federal policies has received some consideration in economics research and policy discussions. One explanation, known as the "Bennett hypothesis," is that the increased availability of financial aid, including loans, has shifted demand upward and resulted in higher tuition (Bennett, 1987). Careful work by Archibald and Feldman (2016) shows that there may be some validity to this claim for non-selective private institutions and for-profit institutions, but there is little evidence to support this explanation for tuition increases at most universities.

The empirical evidence on price discrimination in public higher education has been quite limited. The intellectual origins of discussions of differentiated pricing or "high tuition, high aid" policies go back at least 50 years to work by Hansen and Weisbrod (1969). ${ }^{7}$ In essence, while private universities tended to have high prices and then distribute subsidies via grant aid, public universities provided across-the-board subsidies to in-state students in the form of low tuition. Even as in-state tuition among public universities is - and has been historically — greater at the most research-intensive within each state than at community colleges or non-research institutions, it is still well below the tuition charged by peer institutions in the private sector. Our work demonstrates empirically that price discrimination by family income is increasing at public universities.

\section{Section 3. Empirical Approach}

Our first empirical objective is to quantify the link between tuition and the net tuition charged to students in different income bins. We use a regression framework to describe the extent to which this relationship differs systematically by type of institution and university characteristics.

\footnotetext{
${ }^{6}$ As of Fall 2019, only 11 of 895 national colleges and universities that are ranked by U.S. News and World met full demonstrated need with grant funds, and all 11 were private (Powell and Kerr, 2019).

${ }^{7}$ Because students from relatively affluent families are represented disproportionately in research universities, particularly the state flagships, some have argued that the distribution of public subsidies is regressive (Hansen and Weisbrod, 1969).
} 
With observations at the level of the university $(i)$ and the year $(t)$, we regress net tuition on tuition following the specification:

$$
N T_{i t j}=\beta_{0 j}+\beta_{1 j} \text { Tuition }_{i t}+\boldsymbol{X}_{i t} \boldsymbol{\lambda}_{\boldsymbol{j}}+\gamma_{t j}+\delta_{i j}+\varepsilon_{i t j},
$$

where the outcomes of interest, $N T_{i t j}$, are net tuition by income group $(j)$. The regressions include controls for state-level unemployment, the number of high-school graduates, and year and institution fixed effects $\left(\gamma_{t}\right.$ and $\left.\delta_{i}\right)$. These fixed effects capture secular changes in the entire economy and institution-specific time-invariant characteristics. The coefficient of interest, $\beta_{1}$, measures the passthrough rate: the rate at which tuition changes pass through to net tuition. This parameter answers the question: For each dollar increase in posted tuition and fees, what is the expected change in net tuition for students in the indicated income groups?

We run the baseline regressions separately for four institutional classifications: Carnegie R1 universities, R2 and doctoral institutions, non-research four-year institutions, and community colleges. While these groups capture meaningful differences across institutions, there are significant differences among institutions in measures that may influence an institution's pricing policy, like baseline resources and characteristics of the university's state. Thus, we also present two specifications in which we include interactions between tuition and: 1) per-student salaries for education and general categories (measured at the start of the observation period), and 2) the state median income. These estimates indicate how the pass-through rate changes with institutional characteristics.

We also examine how the distribution of students by family income within each institution has changed with tuition. Tuition pass-through rates describe how aid per student changes with tuition, but the income distribution of enrollment is also an important indicator of whether institutions are becoming more generous. If low-income enrollment shares decrease while per-student aid increases, this is not unambiguously more generous for low-income students. However, if both enrollment and aid increase, the aid policy is more generous for low-income students. Enrollment shares may change with prices through student application and enrollment decisions, and universities may also regulate enrollment shares by income level in the admission process. 
Recent volatility in state appropriations (as discussed in Section 2) raises the question of how state appropriations affect college tuition, other university characteristics, and student outcomes. Our innovation in this context is to examine the link between state appropriations and the net tuition assessed to different income categories. The extent to which appropriations changes impact tuition differently from net tuition depends on how the university prioritizes aid for low-income students relative to other costs. At one extreme, a university would be able to "protect" low-income students if appropriations changes did not affect net tuition; at the other extreme, institutional financial aid could be a casualty of declines in appropriations, with changes in net tuition coming through both an increase in tuition and a reduction in grant aid from a decline in appropriations.

To provide an empirical assessment, we work with the following specification:

$$
N T_{i t j}=\beta_{0 j}+\beta_{1 j} A_{p p r o p}+\boldsymbol{X}_{i t} \lambda_{j}+\gamma_{t j}+\delta_{i j}+\varepsilon_{i t j}
$$

With this analysis, we are interested in addressing two questions: first, are appropriations changes felt "across the board," with all income groups facing similar net tuition increases in response to appropriations changes? In turn, to what extent do institutions differ in their capacity to insulate lowand moderate-income students from the adverse impacts of declining state appropriations.

A long-standing concern is that state appropriations received by an institution reflect political considerations that may indicate a desire of legislators to reward (or punish) specific universities in the budgeting process. To the extent that these considerations may also be related to tuition setting, a concern about endogeneity arises. We follow other researchers, including Bound et al. $(2019,2020)$ and Webber (2017), in arguing that the overall level of state appropriations is an appropriate and necessary instrumental variable for institution-level appropriations. ${ }^{8}$ Several recent papers (Deming and Walters (2017) and Chakrabarti, Gorton, and Lovenheim, (2020)) have used variation in appropriations over time at the state level in conjunction with baseline measures of tuition dependence (a shift-share instrument). While both approaches rely on the exogeneity of appropriations changes at the state level, we prefer to focus on variation generated by the overall level of appropriations,

\footnotetext{
${ }^{8}$ In state budgets, overall higher education expenditures are often a residual claimant after other priorities (K12 , criminal justice, transportation) are satisfied, with revenue cycles and state tax policy outside the influence of higher education leaders. Bound et al. (2019) provide a comprehensive analysis of the determinants of changes in appropriations at the state level.
} 
because the same factors that generate differences among institutions in baseline tuition dependence may also predict institutional adjustments.

\section{Section 4. Estimation and Results}

\section{Net Tuition and Tuition}

Our primary focus is on the extent to which public universities price discriminate in their adjustment in tuition setting and the adjustment of tuition to changes in appropriations. Table 1 shows OLS estimates linking in-state tuition charges to net tuition charged to students in five income groups (\$0-30k; \$30-\$48k; \$48-\$75k; \$75-\$110k, and greater than \$110k). These net tuition measures are for in-state full-time, first-time freshmen and reflect the net tuition (tuition and fees minus grant-based financial aid from all sources) for students who applied for and received federal financial aid in the form of either grants or loans. Each row shows the share of a dollar increase in posted in-state tuition reflected in net tuition for the ascending income groups, with a coefficient of 1 reflecting full passthrough. ${ }^{9}$

Results in Table 1 show striking differences in price differentiation by family income and type of institution. At community colleges and non-research public universities, a tuition increase leads to a near dollar-for-dollar increase in net tuition for students, including those from the lowest income groups. In contrast, tuition changes do not align with dollar-for-dollar increases in net tuition for low- and moderate-income students. At these universities, an increase in in-state tuition of $\$ 1$ is associated with an increase of about 29 cents in net tuition for students with family income less than $\$ 30,000$, moving progressively upward to 40 cents for those in the $\$ 48-75 \mathrm{k}$ range and then rising to about 72 cents for those with the highest income levels who still receive financial aid. The comparison between R1 universities and non-research counterparts indicates heterogeneity in pricing behavior among public universities.

\footnotetext{
${ }^{9}$ Recall that for students already eligible for federal need-based financial aid, each dollar increase in tuition produces a dollar increase in "need" though universities are under no obligation to fund this with increased grant aid. For more affluent students, increased price may impact eligibility for need-based aid.
} 
Table 1: OLS Regressions of Net Tuition on In-State Tuition, by Income Group

$\mathrm{R}$

\begin{tabular}{lccccc}
\hline & $(1)$ & $(2)$ & $(3)$ & $(4)$ & $(5)$ \\
& NT:0-30k & NT:30k-48k & NT:48k-75k & NT:75k-110k & NT:110k+ \\
\hline IS Tuition + Fees & $.288^{* *}$ & $.388^{* * *}$ & $.403 * *$ & $.425^{* * *}$ & $.716^{* * *}$ \\
& $(.131)$ & $(.127)$ & $(.17)$ & $(.144)$ & $(.069)$ \\
Observations & 719 & 719 & 719 & 719 & 719 \\
R-squared & .203 & .217 & .243 & .196 & .6 \\
\hline
\end{tabular}

R2 AND DOCTORAL

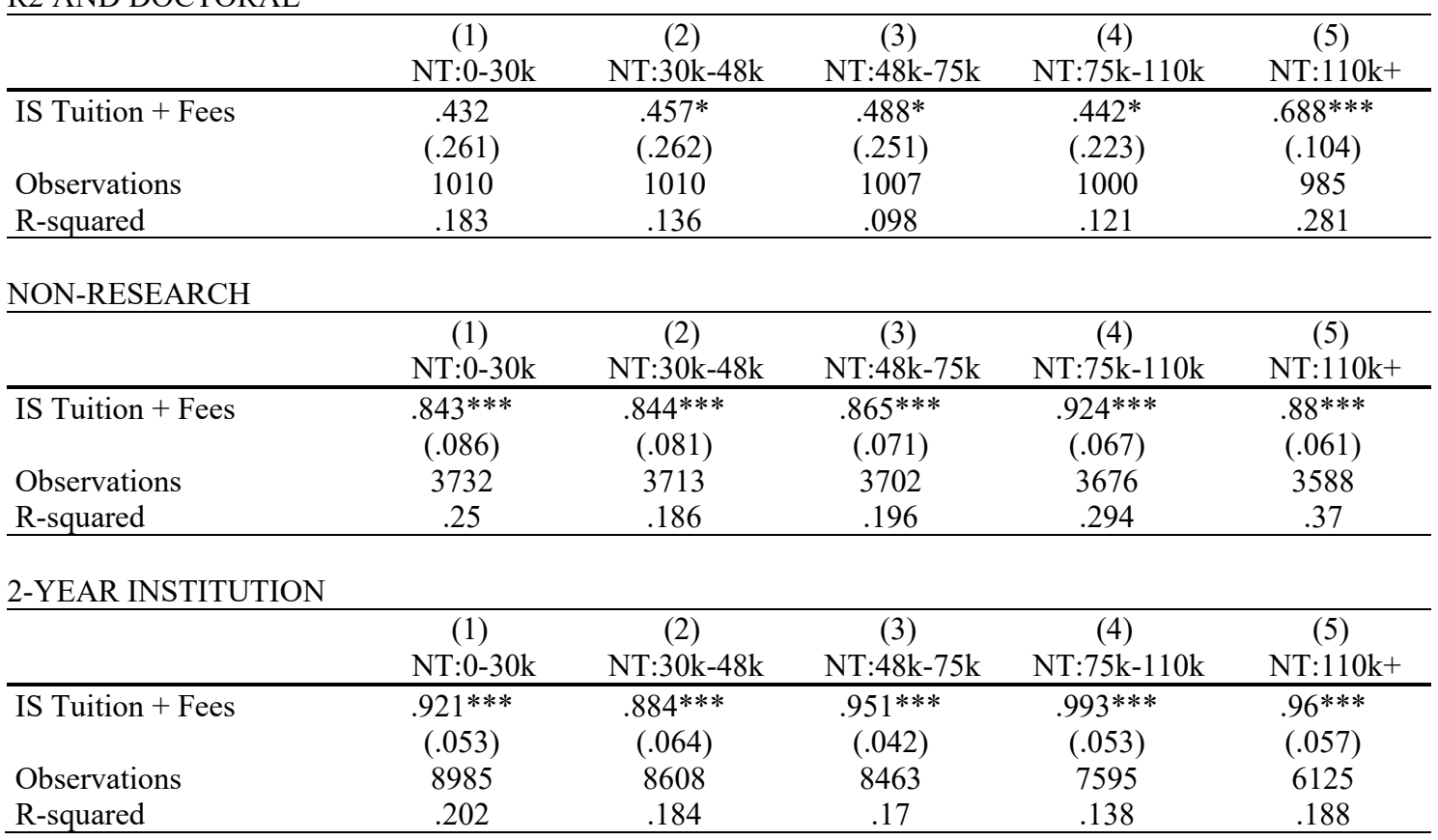

4-YEAR TOTAL WITH BASELINE E\&G INTERACTION

\begin{tabular}{lccccc}
\hline & $(1)$ & $(2)$ & $(3)$ & $(4)$ & $(5)$ \\
& NT:0-30k & NT:30k-48k & NT:48k-75k & NT:75k-110k & NT:110k+ \\
\hline IS Tuition + Fees & $.77 * * *$ & $.868 * * *$ & $.999 * * *$ & $1.082 * * *$ & $.887 * * *$ \\
& $(.147)$ & $(.141)$ & $(.142)$ & $(.136)$ & $(.08)$ \\
Base E\&G (1,000s) x TF & $-.021 * * *$ & $-.022 * *$ & $-.03 * * *$ & $-.032 * * *$ & $-.008 * *$ \\
& $(.005)$ & $(.004)$ & $(.005)$ & $(.005)$ & $(.003)$ \\
Observations & 4246 & 4230 & 4219 & 4195 & 4134 \\
R-squared & .203 & .174 & .187 & .215 & .434 \\
\hline
\end{tabular}

Note: This table shows selected coefficients from regressions of net tuition on in-state tuition and fees by income group and institution type. The final panel shows the same regression but with an interaction of tuition and fees with per-student salaries for education and general categories in 2008 (in 1,000s). All regressions include year and university fixed effects, state-level unemployment rate, and high-school graduating cohort. The regressions are weighted by baseline enrollment. Standard errors are clustered at the university level. 
Interaction Effects - Varying Market Characteristics

The differences across types of public universities stem from differences in characteristics such as resources per student. And, even within the broad categories, there remain substantial differences among universities. This section describes how two university characteristicseducational salary expenditures per student and state median income-relate to pricing differences across income groups within and across university types.

Expenditures per student, which may reflect other sources of support like university endowments or research capacity, may impact the extent to which universities can compensate for higher tuition and fees with grant aid. In the final panel of Table 1, estimates of the interaction effect show how differences in expenditures per student (measure in 2007-08) are associated with the passthrough rate. To illustrate, at institutions with baseline per-student salaries for education and general in the $75^{\text {th }}$ percentile, or approximately $\$ 12,000$ per student (for example, Florida State University, Georgia State University, and the University of Oregon), the estimated pass-through rate for the lowest income bin is about 52 cents per dollar. For students in the $\$ 48-75$ income bin, the passthrough rate is about 64 cents per dollar. A $25^{\text {th }}$-percentile institution has per-student education and general salaries around $\$ 7,000$ (examples include many California State University campuses). For these institutions, the pass-through rates for the $\$ 0-\$ 30 \mathrm{k}$ and the $\$ 48-\$ 75 \mathrm{k}$ brackets are approximately 62 and 79 cents per dollar, respectively. Similar estimates by institution type are presented in Appendix Table $1 .^{10}$

\section{Appropriations, Tuition, and Net Tuition}

Among the multiple mechanisms potentially driving tuition changes at public universities, the role of adjustments in state appropriations is particularly salient, given the direct impact on institutional budgets. In Table 2, we show the impact of changes in appropriations on net tuition and

\footnotetext{
${ }^{10}$ In addition, we have considered whether the socio-economic status in the state impacts the degree of differentiation in pricing as states with more potential students from high-income families may be able to raise tuition more while also insulating low-income students from tuition increases. Regressions of net tuition on tuition and interactions with the state's median income (Appendix Table 2) show a statistically significant role for this channel. For each $\$ 1,000$ increase in the state's median income, the pass-through rate at four-year institutions overall is reduced by between 1 and 2 cents per dollar of tuition for students with family incomes less than $\$ 110 \mathrm{k}$.
} 
tuition, using overall state appropriations as an instrument for appropriations received by the institution. The columns distinguish impacts on net tuition for different income ranges, and tuition in the final column; the rows present the effects by type of institution. The instrumental variables estimates in the final column of Table 2 can be interpreted as follows: for each $\$ 1$ decrease in appropriations per student at R1 public universities, in-state tuition rates can be expected to rise by 54 cents, while at R2 and doctoral public universities and non-research public universities, the expected tuition increases would be 41.5 cents and 30.4 cents, respectively. For low-income students, net tuition impacts are quantitatively similar to the tuition impacts for students at R1 and non-research universities, while imprecisely estimated for those at $\mathrm{R} 2$ and doctoral universities. While students in the lowest income group at non-research institutions can expect a decrease in net tuition of about 35 cents for each dollar increase in appropriations, the corresponding decrease in net tuition is about 54 cents for students at R1 universities. Where appropriations changes "bite" with the biggest change in net tuition is for students in the $\$ 48-75 \mathrm{k}$ and $\$ 75-110 \mathrm{k}$ family income bins. When the net tuition effect exceeds the tuition effect, increases in tuition caused by appropriations declines are not simply passed on to low-income students, but financial aid is also reduced.

The implication is that, on average, appropriations declines can be expected to be passed on to students across all income ranges even as the changes are less than dollar-for-dollar. Indeed, for those in aid-eligible income bins above the poorest at R1 and non-research universities, estimated impacts of appropriations changes on net tuition tend to exceed the baseline tuition estimates, implying that appropriations changes are not only passed on in full but may also impact the budget for institutional financial aid. 
Table 2: IV Regressions of Tuition and Net Tuition on Appropriations per Student

R1

\begin{tabular}{lcccccc}
\hline & $(1)$ & $(2)$ & $(3)$ & $(4)$ & $(5)$ & $(6)$ \\
& NT:0-30k & NT:30k-48k & NT:48k-75k & NT:75k-110k & NT:110k+ & IS T+F \\
\hline State & $-.542^{* *}$ & $-.538^{* *}$ & $-.77^{* * *}$ & $-1.263 * * *$ & $-.686^{* * *}$ & $-.504 * * *$ \\
Appr./Student & & & & & & \\
& $(.253)$ & $(.231)$ & $(.276)$ & $(.404)$ & $(.234)$ & $(.158)$ \\
Observations & 708 & 708 & 708 & 708 & 708 & 718 \\
First-Stage F & 17.608 & 17.608 & 17.608 & 17.608 & 17.608 & 17.617 \\
\hline
\end{tabular}

R2 AND DOCTORAL

\begin{tabular}{lcccccc}
\hline & $(1)$ & $(2)$ & $(3)$ & $(4)$ & $(5)$ & $(6)$ \\
& NT:0-30k & NT:30k-48k & NT:48k-75k & NT:75k-110k & NT:110k+ & IS T+F \\
\hline State & -.161 & $-.286^{*}$ & $-.417^{* * *}$ & $-.428^{* * *}$ & -.207 & $-.415^{* * *}$ \\
Appr./Student & & & & & & \\
& $(.159)$ & $(.151)$ & $(.161)$ & $(.153)$ & $(.133)$ & $(.106)$ \\
Observations & 1005 & 1005 & 1002 & 995 & 979 & 1005 \\
First-Stage F & 54.366 & 54.366 & 54.411 & 54.631 & 54.535 & 54.366 \\
\hline
\end{tabular}

NON-RESEARCH

\begin{tabular}{lcccccc}
\hline & $(1)$ & $(2)$ & $(3)$ & $(4)$ & $(5)$ & $(6)$ \\
& NT:0-30k & NT:30k-48k & NT:48k-75k & NT:75k-110k & NT:110k+ & IS T+F \\
\hline State & $-.352 * * *$ & $-.488^{* * *}$ & $-.503 * * *$ & $-.703 * * *$ & $-.25 * * *$ & $-.304 * * *$ \\
Appr./Student & & & & & & \\
& $(.108)$ & $(.111)$ & $(.107)$ & $(.107)$ & $(.085)$ & $(.046)$ \\
Observations & 3459 & 3439 & 3428 & 3402 & 3314 & 3459 \\
First-Stage F & 240.925 & 243.433 & 246.229 & 246.006 & 256.942 & 240.925 \\
\hline
\end{tabular}

Note: This table shows selected coefficients from a regression of net tuition on appropriations per student by income group and institution type. The final column shows a regression of posted tuition on appropriations per student. All regressions include year and university fixed effects, state-level unemployment rate, and highschool graduating cohort size. The instrument is the state-level appropriations from the State Higher Education Executive Officers Association (SHEEO) per high school graduate in the state. The regressions are weighted by baseline enrollment. Standard errors are clustered at the university level.

These results complement prior research, which has shown the impact of appropriations on tuition levels and net tuition revenues, by demonstrating the extent to which appropriations affect pricing across the income distribution. ${ }^{11}$ Work by Webber (2017) assessing the response of net tuition - defined as tuition revenues from all sources (in-state, out-of-state, and graduate) — to appropriations changes aligns most closely with our results. However, his empirical approach captures

\footnotetext{
11 To place these estimates in the context of prior research requires some comparison across specifications. Appendix Table 3 provides estimates of the effect of appropriations on tuition and net tuition measures in specifications where appropriations are in logs, levels, and per-student. The logged version is most comparable to estimates from Bound et al. (2019), who find a coefficient on logged appropriations of -0.157 for public research universities, and -0.338 for the more selective set of AAU universities. Our estimates of -0.285 for R1, -0.311 for $\mathrm{R} 2$ and Doctoral, and -0.165 for non-research public universities are in line with these prior estimates; differences are largely explained by differences in the time period studied.
} 
all grant aid rather than distinguishing among family income groups. Using data from 1987 to 2014, he finds that each dollar reduction in state appropriations corresponds to an increase of 32 cents in tuition revenue, with effects somewhat larger at doctorate-granting institutions.

\section{Decomposition of Change in Net Tuition: State Appropriations and the Residual}

Returning to the overall changes in tuition and net tuition shown in Figure 1, we consider the extent to which the 2008 to 2017 changes in net tuition and tuition can be explained by the shifts in state appropriations versus other factors, including demand shocks and other revenue and cost shocks. We consider two distinct intervals: from 2007-08 to 2011-12, appropriations contracted markedly, while they recovered (to a greater degree for non-research than research universities) in the subsequent years.

Figure 2 illustrates with a decomposition. It shows predicted changes in net tuition and tuition based on changes in state appropriations (using the estimates from Table 3), as well as the observed changes in net tuition and tuition. Between 2007-08 to 2011-12, realized tuition changes exceeded those predicted by declines in appropriations alone at all types of institutions. Baum et al. (2018) also find that residual growth in tuition levels has been appreciably greater in recent years than can be explained by changes in state appropriations or other sources of government support. Yet, for lowand moderate-income students at R1 universities, realized net tuition increases were less than those predicted from the appropriations changes (which fell by $\$ 2,530$ per student on average), implying negative residual adjustments lessened the impact of the appropriations change. This divergence is particularly apparent for students from moderate-income families (family incomes of $\$ 48-\$ 110 \mathrm{k}$ ). To illustrate, for students from families in the $\$ 48$ - $\$ 75 \mathrm{k}$ income bin, the predicted increase in net tuition of $\$ 2,088$ aligned with a realized change close to zero, implying a near-complete offset. For the non-research universities where appropriations per student declined by about $\$ 1,209$, the predicted increases in net tuition are generally less than (or about the same as) the observed increases.

In the second period (from 2012-13 to 2017-18), because appropriations per student increased - recovering $96 \%$ of the first-period loss for non-research universities and $15 \%$ for R1 universities - the predicted changes point to declines in both net tuition and tuition. Yet, while net tuition did decline, tuition rose across all institutional categories. The actual net tuition rates fell 
Figure 2. Decomposition of Changes in Tuition and Net Tuition, 2008-2017

Panel A. Change in Actual and Predicted Net Tuition, 2008-09 to 2011-12

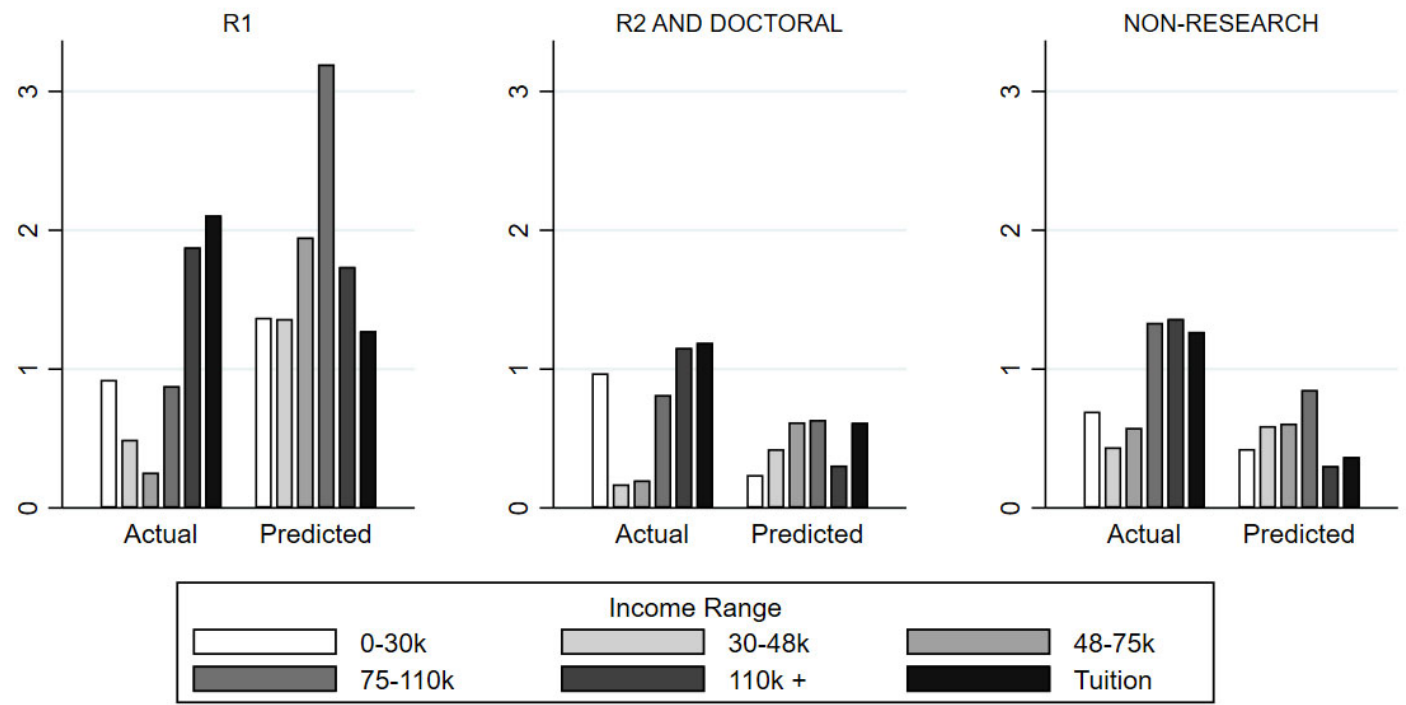

Panel B. Change in Actual and Predicted Net Tuition, 2012-13 to 2017-18

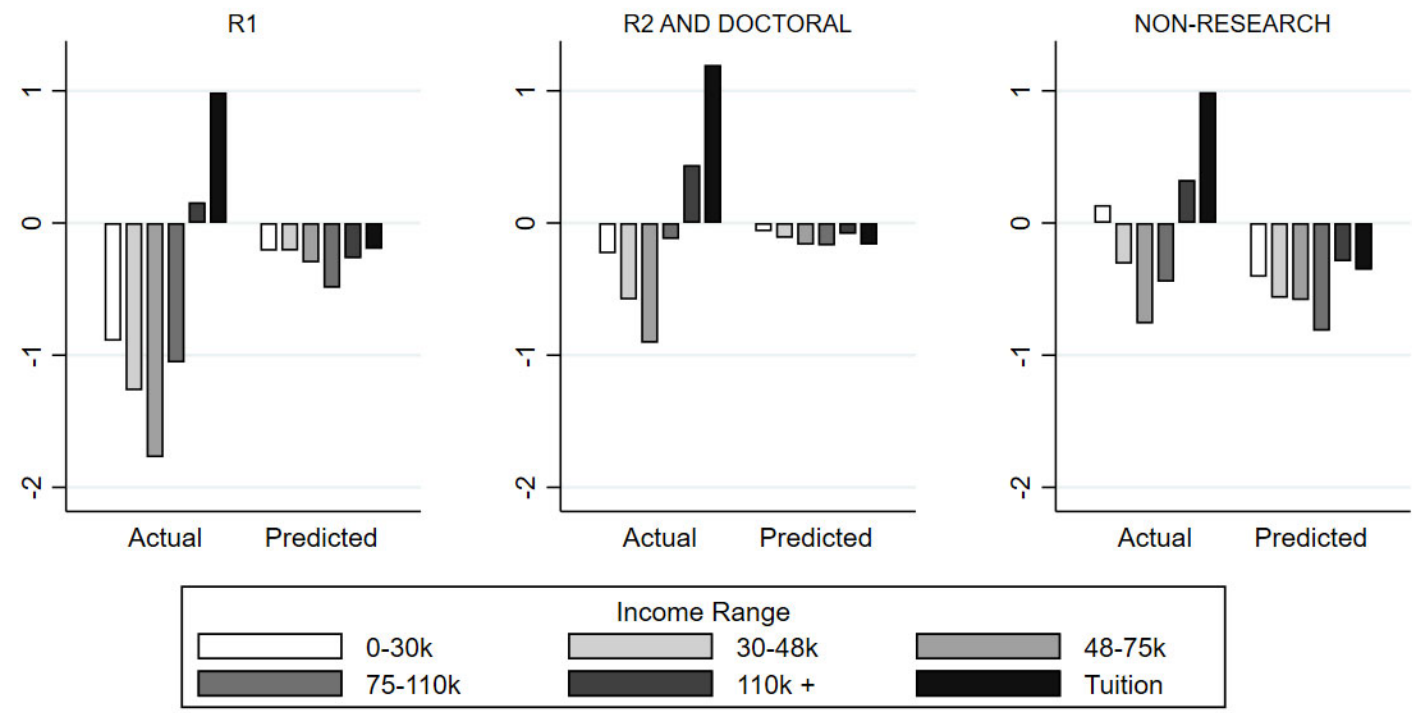

Note: This figure shows changes in actual and predicted prices by income group in $\$ 1,000$ s of 2019 dollars. Panel A shows 2008-09 through 2011-12, and panel B shows 2012-13 through 2017-18. Predicted changes are calculated by multiplying the change in appropriations by the IV estimate of the effects of appropriations on net tuition (displayed in Table.3), then taking the enrollment-weighted average of this predicted change across institutions. For reference, appropriations per student declined in the first period by $\$ 2,530$ for R1, $\$ 1,482$ for R2 and doctoral, and $-\$ 1,209$ for non-research universities. Appropriations per student increased in the second period by $\$ 388$ for R1, 396 for R2, and $\$ 1,160$ for non-research universities. 
considerably more than predicted in the low- and moderate-income categories for students at R1 universities. For non-research universities, the predicted declines in net tuition are greater than the actuals for all but the $\$ 48 \mathrm{k}-\$ 75 \mathrm{k}$ family income bin. Broadly, R1 institutions showed larger-thanpredicted net tuition declines while the realized declines at non-research tended to lag the predicted declines.

\section{Tuition and the Distribution of Students}

Shifting from the examination of the progressivity of pricing to relative quantities, we explore how the relative representation of students by family income changes with tuition levels and state appropriations. Table 3 shows how enrollment by income bin varies with tuition levels. In the first five columns, the dependent variable is the percent of first-time, first-year, in-state students in the income bin. The dependent variable in the final column is the total number of first-time, first-year, instate students. At the R1 institutions, increasing tuition yields an increase in aided students overall in the four lowest income groups (about 0.315 pp per $\$ 1,000$ for those with income less than $\$ 30,000$, 0.335 for those in the $\$ 30,000-\$ 48,000$ range, 0.407 for those in the $\$ 48,000$ to $\$ 75,000$ bin, and 0.304 in the $\$ 75,000$ to $\$ 110,000$ bin). At other types of institutions, effects on enrollment composition and total enrollment are generally not statistically significant. 
Table 3: Regression of Enrollment Share by Income Category on In-State Tuition and Fees

\begin{tabular}{lccccccc}
\hline R1 & $(1)$ & $(2)$ & $(3)$ & $(4)$ & $(5)$ & $(6)$ & $(7)$ \\
& $0-30 \mathrm{k}$ & $31 \mathrm{k}-48 \mathrm{k}$ & $48 \mathrm{k}-75 \mathrm{k}$ & $\begin{array}{c}75 \mathrm{k}- \\
110 \mathrm{k}\end{array}$ & $110 \mathrm{k}+$ & NoAid & Total \\
\hline $\begin{array}{l}\text { IS Tuition + Fees, } \\
1,000 \mathrm{~s}\end{array}$ & $.315^{* *}$ & $.335^{* * *}$ & $.407^{* * *}$ & $.304^{* * *}$ & .187 & $-1.548^{* * *}$ & $-.062^{*}$ \\
& & & & & & & \\
Observations & $7144)$ & $(.077)$ & $(.077)$ & $(.095)$ & $(.115)$ & $(.318)$ & $(.032)$ \\
R-squared & .241 & 719 & 719 & 719 & 719 & 719 & 729 \\
& & .161 & .359 & .385 & .41 & .373 & .149 \\
\hline
\end{tabular}

R2 AND DOCTORAL

\begin{tabular}{|c|c|c|c|c|c|c|c|}
\hline & (1) & (2) & (3) & (4) & (5) & (6) & (7) \\
\hline & $0-30 \mathrm{k}$ & $31 \mathrm{k}-48 \mathrm{k}$ & $48 \mathrm{k}-75 \mathrm{k}$ & $\begin{array}{l}75 \mathrm{k}- \\
110 \mathrm{k}\end{array}$ & $110 \mathrm{k}_{-}+$ & NoAid & Total \\
\hline \multirow{2}{*}{$\begin{array}{l}\text { IS Tuition + Fees } \\
1,000 \mathrm{~s}\end{array}$} & .277 & .163 & .196 & .173 & .075 & -.883 & .049 \\
\hline & $(.239)$ & $(.111)$ & (.133) & $(.172)$ & $(.292)$ & $(.553)$ & $(.031)$ \\
\hline Observations & 1010 & 1010 & 1010 & 1010 & 1010 & 1010 & 1010 \\
\hline R-squared & .252 & .043 & .13 & .031 & .273 & .221 & .162 \\
\hline
\end{tabular}

NON-RESEARCH

\begin{tabular}{lllllllc} 
& $(1)$ & $(2)$ & $(3)$ & $(4)$ & $(5)$ & $(6)$ & $(7)$ \\
& $0-30 \mathrm{k}$ & $31 \mathrm{k}-48 \mathrm{k}$ & $48 \mathrm{k}-75 \mathrm{k}$ & $75 \mathrm{k}-110 \mathrm{k}$ & $110 \mathrm{k}+$ & NoAid & Total \\
\hline IS Tuition + Fees, & .061 & -.411 & -.088 & -.288 & -.354 & 1.08 & $.028^{*}$ \\
1,000s & & & & & & & \\
& $(.702)$ & $(.447)$ & $(.388)$ & $(.366)$ & $(.35)$ & $(2.116)$ & $(.016)$ \\
Observations & 3732 & 3732 & 3732 & 3732 & 3732 & 3732 & 3732 \\
R-squared & .021 & .014 & .015 & .011 & .11 & .005 & .107 \\
\hline
\end{tabular}

Note: The first six columns show selected coefficients from regressions where the dependent variable is the percentage of in-state students in each income group (from 0 to 100), and the independent variable is in-state tuition and fees, in thousands. The final column shows the effects on the total number of in-state students. The regressions are weighted by baseline enrollment. Standard errors are clustered at the university level. 


\section{Section 5. Conclusion and Further Thoughts}

The popular press has devoted much ink to the potentially deleterious effects of tuition increases on opportunities for low-income students (Clark, 2016; Dickler, 2016; Douglas-Gabriel, 2016). We present evidence that runs counter to this narrative; the impact of increasing tuition levels on low-income students is nuanced, varying by institutional characteristics. Even as tuition levels increase, low-income students attending R1 public universities may see increases in aid that more than compensate for tuition increases. To this end, debates among advocates for "free college" and proponents of market-driven tuition policies are likely to miss the most salient issues if they fail to look at the progressivity of tuition pricing rather than just the price charged to students from highincome families.

Our evidence points to increasing average tuition coupled with greater tuition stratification across public universities. The most resource-intensive universities have increased price discrimination by income to such a degree that students from low- and middle-income families now face lower net tuition charges than they did a decade ago. Our analysis suggests that appropriations declines have not contributed to increasing price discrimination, so other forces are at work. Universities have become increasingly stratified by resources, and higher-resource institutions have been successful at gaining alternative forms of revenue while increasing the degree of price discrimination by income. A complete understanding of the trend toward the high-tuition, high-aid model requires more extensive modeling of public universities' objectives, revenue streams, and interactions with state governments. Yet the empirical evidence demonstrates that tuition increases do not necessarily coincide with increases in net tuition at public universities for low- and middle-income students. 


\section{Acknowledgements}

William Winston and Ramiro Burga provided excellent research assistance. We are also exceedingly grateful to Breno Braga and Gaurav Khanna for help with data and code on closely related prior work. We thank Joshua Goodman and Jeff Smith for insightful and constructive comments. This work has benefited from comments from seminar participants at the University of Wisconsin-Madison, Duke University, the Summer Higher Education Seminar Series organized by Dominique Baker and Robert Kelchen, and the Association for Public Policy Analysis and Management Annual Conference. Sarah Turner acknowledges the Bankard Fund for Political Economy at UVa for financial support. 


\section{$\underline{\text { References }}$}

Archibald, Robert B., and David H. Feldman. 2016. "Federal Financial Aid Policy and College Behavior."

Baum, Sandy, Michael S McPherson, Breno Braga, and Sarah Minton. 2018. "Tuition and State Appropriations: Using Evidence and Logic to Gain Perspective." Washington, DC: Urban Institute. https://www.urban.org/sites/default/files/publication/96791/tuition_and_state_appropriations_1.pdf.

Bennett, William J. 1987. "Our Greedy Colleges." The New York Times, February 18, 1987.

Bound, John, Breno Braga, Gaurav Khanna, and Sarah Turner. 2019. "Public Universities: The Supply Side of Building a Skilled Workforce." RSF: The Russell Sage Foundation Journal of the Social Sciences 5 (5): 43. https://doi.org/10.7758/rsf.2019.5.5.03.

Bound, John, Breno Braga, Gaurav Khanna, and Sarah Turner. 2020. "A Passage to America: University Funding and International Students." American Economic Journal: Economic Policy, 12 (1): 97126.

Carnegie Foundation for the Advancement of Teaching. 2011. "The Carnegie Classification of Institutions of Higher Education, 2010 Edition." Stanford, CA.

Chakrabarti, Rajashri, Nicole Gorton, and Michael F Lovenheim. 2020. "State Investment in Higher Education: Effects on Human Capital Formation, Student Debt, and Long-Term Financial Outcomes of Students." NBER Working Paper 27885. http://www.nber.org/papers/w27885.

Clark, Kim. 2016. "College Costs Hit New Record Highs in 2016." Money, October 26, 2016. https://money.com/college-costs-record-2016/.

Courant, Paul N., Michael McPherson, and Alexandra M. Resch. 2006. "The Public Role in Higher Education." National Tax Journal 59 (2): 291-318. https://doi.org/10.17310/ntj.2006.2.06.

Dickler, Jessica. 2016. "College Costs Are Out Of Control." CNBC.com, July 14, 2016. https://www.cnbc.com/2016/07/12/college-costs-are-out-of-control.html.

Deming, David, and Christopher Walters. 2017. "The Impact of Price Caps and Spending Cuts on U.S. Postsecondary Attainment." https://scholar.harvard.edu/files/ddeming/files/DW_Aug2017.pdf.

Douglas-Gabriel, Danielle. 2016. "College Costs Rising Faster than Financial Aid, Report Says." The Washington Post, October 26, 2016. https:/www.washingtonpost.com/news/gradepoint/wp/2016/10/26/college-costs-rising-faster-than-financial-aid-report-says.

Epple, Dennis, Richard Romano, Sinan Sarpça, Holger Sieg, and Melanie Zaber. 2019. "Market Power and Price Discrimination in the US Market for Higher Education." RAND Journal of Economics 50 (1): 201-25. https://doi.org/10.1111/1756-2171.12267.

Hansen, W. Lee, and Burton Weisbrod. 1969. "The Distribution of Costs and Direct Benefits of Public Higher Education: The Case of California." Journal of Human Resources 4 (2): 176-91. 
Ma, Jennifer, Matea Pender, and CJ Libassi. 2020. "Trends in College Pricing and Student Aid 2020." New York: College Board.

National Association of State Student Grant and Aid Programs (NASSGAP). 2019. "50th Annual Survey Report on State-Sponsored Student Financial Aid."

Powell, Farran, and Emma Kerr. 2019. "Schools That Meet Full Financial Need With No Loans." https://doi.org/10.1016/j.solener.2019.02.027.

Rothschild, Michael, and Lawrence J. White. 1993. "The University in the Marketplace: Some Insights and Some Puzzles." In Studies of Supply and Demand in Higher Education, 11-42. University of Chicago Press. https://doi.org/10.3386/w3853.

Rothschild, Michael, and Lawrence J. White. 1995. "The Analytics of the Pricing of Higher Education and Other Services in Which the Customers Are Inputs." Journal of Political Economy 103 (3): 573-86.

State Higher Education Executive Officers Association (SHEEO). 2020. "State Higher Education Finance FY 2019." https://shef.sheeo.org/report/.

Webber, Douglas A. 2017. "State Divestment and Tuition at Public Institutions." Economics of Education Review 60: 1-4. https://doi.org/10.1016/j.econedurev.2017.07.007. 


\section{Online Appendix Tables and Figures}

Appendix Figure 1: Difference between Flagship and Average Non-Research University Net Tuition by State and Income Group
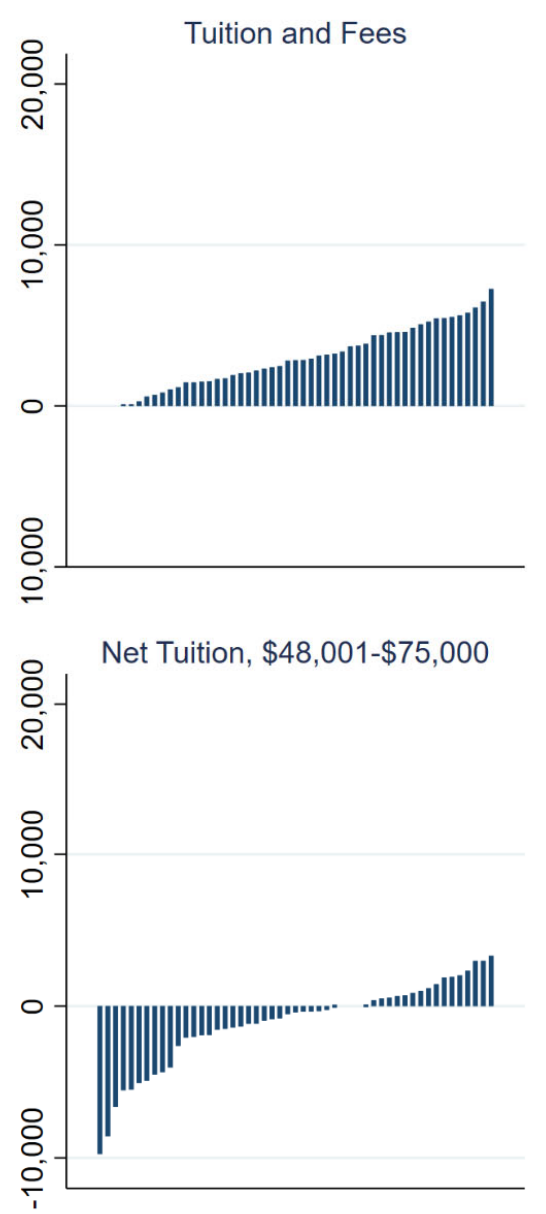
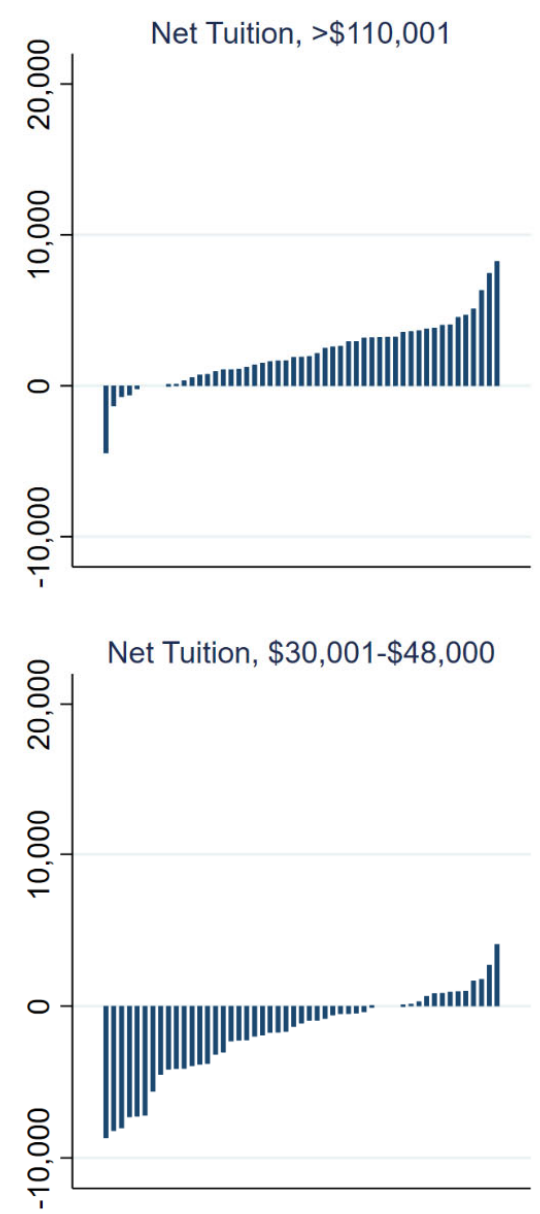
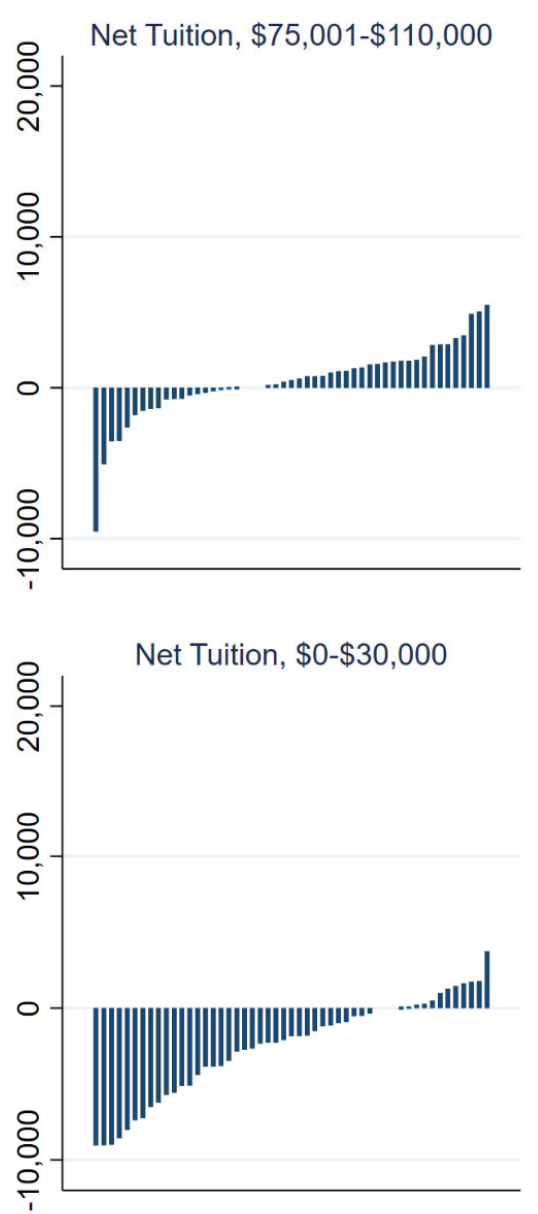

Note: The figure shows the difference between net tuition at the flagship university and net tuition at the average non-research university by state and income group. Each panel shows an income group, and each bar is a state. 
Appendix Table 1: OLS Net Tuition on In-State Tuition and Baseline Education and General per Student R1

\begin{tabular}{|c|c|c|c|c|c|}
\hline & $\begin{array}{c}(1) \\
\text { NT:0-30k }\end{array}$ & $\begin{array}{c}(2) \\
\text { NT:30k-48k }\end{array}$ & $\begin{array}{c}(3) \\
\text { NT:48k-75k }\end{array}$ & $\begin{array}{c}(4) \\
\text { NT:75k-110k }\end{array}$ & $\begin{array}{c}(5) \\
\text { NT:110k+ }\end{array}$ \\
\hline IS Tuition + Fees & $\begin{array}{c}.837 * * * \\
(.277)\end{array}$ & $\begin{array}{c}.896^{* * * *} \\
(.251)\end{array}$ & $\begin{array}{l}.92 * * * \\
(.296)\end{array}$ & $\begin{array}{c}1.052 * * * \\
(.292)\end{array}$ & $\begin{array}{c}.883 * * * \\
(.149)\end{array}$ \\
\hline Base $E \& G(1,000 s) \times T F$ & $\begin{array}{c}-.023 * * * \\
(.008)\end{array}$ & $\begin{array}{c}-.022 * * * \\
(.007)\end{array}$ & $\begin{array}{c}-.023^{* *} \\
(.01)\end{array}$ & $\begin{array}{c}-.027 * * * \\
(.009)\end{array}$ & $\begin{array}{l}-.007 \\
(.004)\end{array}$ \\
\hline $\begin{array}{l}\text { Observations } \\
\text { R-squared }\end{array}$ & $\begin{array}{l}679 \\
.229\end{array}$ & $\begin{array}{l}679 \\
.242\end{array}$ & $\begin{array}{l}679 \\
.297\end{array}$ & $\begin{array}{r}679 \\
.27\end{array}$ & $\begin{array}{l}679 \\
.623\end{array}$ \\
\hline \multicolumn{6}{|l|}{ R2 AND DOCTORAL } \\
\hline & $\begin{array}{c}(1) \\
\text { NT:0-30k }\end{array}$ & $\begin{array}{c}(2) \\
\mathrm{NT}: 30 \mathrm{k}-48 \mathrm{k}\end{array}$ & $\begin{array}{c}(3) \\
\text { NT: } 48 \mathrm{k}-75 \mathrm{k}\end{array}$ & $\begin{array}{c}\text { (4) } \\
\text { NT:75k-110k }\end{array}$ & $\begin{array}{c}(5) \\
\text { NT:110k+ }\end{array}$ \\
\hline IS Tuition + Fees & $\begin{array}{c}.363 \\
(.463)\end{array}$ & $\begin{array}{c}.646 \\
(.468)\end{array}$ & $\begin{array}{l}.871 * * \\
(.377)\end{array}$ & $\begin{array}{l}.99 * * * \\
(.281)\end{array}$ & $\begin{array}{c}1.038 * * * \\
(.22)\end{array}$ \\
\hline Base $\mathrm{E} \& \mathrm{G}(1,000 \mathrm{~s}) \times \mathrm{TF}$ & $\begin{array}{l}.001 \\
(.047)\end{array}$ & $\begin{array}{l}-.018 \\
(.047)\end{array}$ & $\begin{array}{c}-.04 \\
(.041)\end{array}$ & $\begin{array}{l}-.055^{*} \\
(.033)\end{array}$ & $\begin{array}{l}-.032 * \\
(.017)\end{array}$ \\
\hline $\begin{array}{l}\text { Observations } \\
\text { R-squared }\end{array}$ & $\begin{array}{l}880 \\
.174\end{array}$ & $\begin{array}{l}880 \\
.13\end{array}$ & $\begin{array}{l}878 \\
.105\end{array}$ & $\begin{array}{l}871 \\
.144\end{array}$ & $\begin{array}{l}862 \\
.326\end{array}$ \\
\hline \multicolumn{6}{|l|}{ NON-RESEARCH } \\
\hline & $\begin{array}{c}(1) \\
\text { NT:0-30k } \\
\end{array}$ & $\begin{array}{c}(2) \\
\text { NT:30k-48k } \\
\end{array}$ & $\begin{array}{c}(3) \\
\mathrm{NT}: 48 \mathrm{k}-75 \mathrm{k} \\
\end{array}$ & $\begin{array}{c}(4) \\
\text { NT:75k-110k }\end{array}$ & $\begin{array}{c}(5) \\
\mathrm{NT}: 110 \mathrm{k}+ \\
\end{array}$ \\
\hline IS Tuition + Fees & $\begin{array}{c}.893 * * * \\
(.206)\end{array}$ & $\begin{array}{c}.973 * * * \\
(.238)\end{array}$ & $\begin{array}{c}1.123 * * * \\
(.259)\end{array}$ & $\begin{array}{c}1.219^{* * *} \\
(.257)\end{array}$ & $\begin{array}{c}.813 * * * \\
(.158)\end{array}$ \\
\hline Base $\mathrm{E} \& \mathrm{G}(1,000 \mathrm{~s}) \times \mathrm{TF}$ & $\begin{array}{l}-.022 \\
(.021)\end{array}$ & $\begin{array}{l}-.026 \\
(.027)\end{array}$ & $\begin{array}{l}-.037 \\
(.031)\end{array}$ & $\begin{array}{l}-.035 \\
(.028)\end{array}$ & $\begin{array}{l}.006 \\
(.016)\end{array}$ \\
\hline $\begin{array}{l}\text { Observations } \\
\text { R-squared }\end{array}$ & $\begin{array}{l}2687 \\
.281 \\
\end{array}$ & $\begin{array}{c}2671 \\
.211 \\
\end{array}$ & $\begin{array}{l}2662 \\
.198 \\
\end{array}$ & $\begin{array}{c}2645 \\
.305 \\
\end{array}$ & $\begin{array}{c}2593 \\
.372 \\
\end{array}$ \\
\hline \multicolumn{6}{|l|}{ 2-YEAR INSTITUTION } \\
\hline & $\begin{array}{c}(1) \\
\text { NT:0-30k } \\
\end{array}$ & $\begin{array}{c}(2) \\
\text { NT:30k-48k } \\
\end{array}$ & $\begin{array}{c}(3) \\
\mathrm{NT}: 48 \mathrm{k}-75 \mathrm{k} \\
\end{array}$ & $\begin{array}{c}(4) \\
\text { NT:75k-110k } \\
\end{array}$ & $\begin{array}{c}(5) \\
\text { NT:110k+ } \\
\end{array}$ \\
\hline IS Tuition + Fees & $\begin{array}{c}1.423 * * * \\
(.191)\end{array}$ & $\begin{array}{l}1.279 * * * \\
(.19)\end{array}$ & $\begin{array}{c}1.155^{* * *} \\
(.194)\end{array}$ & $\begin{array}{c}.995 * * * \\
(.173)\end{array}$ & $\begin{array}{c}.795 * * * \\
(.21)\end{array}$ \\
\hline Base $E \& G(1,000 s) \times T F$ & $\begin{array}{c}-.085^{* *} \\
(.035)\end{array}$ & $\begin{array}{l}-.06 \\
(.037)\end{array}$ & $\begin{array}{l}-.039 \\
(.035)\end{array}$ & $\begin{array}{l}-.01 \\
(.03)\end{array}$ & $\begin{array}{l}.028 \\
(.035)\end{array}$ \\
\hline $\begin{array}{l}\text { Observations } \\
\text { R-squared }\end{array}$ & $\begin{array}{c}3039 \\
.249\end{array}$ & $\begin{array}{l}3016 \\
.195\end{array}$ & $\begin{array}{l}2995 \\
.194\end{array}$ & $\begin{array}{l}2834 \\
.154\end{array}$ & $\begin{array}{r}2455 \\
.224\end{array}$ \\
\hline \multicolumn{6}{|c|}{ 4-YEAR INSTITUTION, TOTAL } \\
\hline & $\begin{array}{c}(1) \\
\text { NT:0-30k }\end{array}$ & $\begin{array}{c}(2) \\
\mathrm{NT}: 30 \mathrm{k}-48 \mathrm{k}\end{array}$ & $\begin{array}{c}(3) \\
\mathrm{NT}: 48 \mathrm{k}-75 \mathrm{k} \\
\end{array}$ & $\begin{array}{c}(4) \\
\text { NT:75k-110k }\end{array}$ & $\begin{array}{c}(5) \\
\text { NT:110k+ }\end{array}$ \\
\hline IS Tuition + Fees & $\begin{array}{l}.77 * * * \\
(.147)\end{array}$ & $\begin{array}{c}.868 * * * \\
(.141)\end{array}$ & $\begin{array}{c}.999 * * * \\
(.142)\end{array}$ & $\begin{array}{c}1.082 * * * \\
(.136)\end{array}$ & $\begin{array}{c}.887 * * * \\
(.08)\end{array}$ \\
\hline Base $\mathrm{E} \& \mathrm{G}(1,000 \mathrm{~s}) \times \mathrm{TF}$ & $\begin{array}{c}-.021 * * * \\
(.005)\end{array}$ & $\begin{array}{c}-.022 * * * \\
(.004)\end{array}$ & $\begin{array}{c}-.03 * * * \\
(.005)\end{array}$ & $\begin{array}{c}-.032 * * * \\
(.005)\end{array}$ & $\begin{array}{c}-.008^{* *} \\
(.003)\end{array}$ \\
\hline Observations & 4246 & 4230 & 4219 & 4195 & 4134 \\
\hline R-squared & .203 & .174 & .187 & .215 & .434 \\
\hline
\end{tabular}

Note: The table shows selected coefficients from a regression of net tuition on in-state tuition and fees, and an interaction with per-student salaries for education and general in 2008 (in 1,000s). All regressions include year and university fixed effects, state-level unemployment rate, and high-school graduating cohort. The regressions are weighted by baseline enrollment. Standard errors are clustered at the university level. 
Appendix Table 2: OLS Net Tuition on In-State Tuition and State Median Income

R1

\begin{tabular}{lccccc}
\hline & $(1)$ & $(2)$ & $(3)$ & $(4)$ & $(5)$ \\
& NT:0-30k & NT:30k-48k & NT:48k-75k & NT:75k-110k & NT:110k+ \\
\hline IS Tuition + Fees & .5 & $1.089^{* * *}$ & $1.772^{* * *}$ & $2.043^{* * *}$ & $1.109^{* * *}$ \\
& $. .408)$ & $(.266)$ & $(.415)$ & $.454)$ & $(.273)$ \\
Median Inc x IS TF & -.004 & $-.012^{* * *}$ & $-.023 * * *$ & $-.026^{* * *}$ & $-.006^{*}$ \\
& $(.006)$ & $(.004)$ & $(.006)$ & $(.007)$ & $(.004)$ \\
Observations & 679 & 679 & 679 & 679 & 679 \\
R-squared & .198 & .223 & .313 & .293 & .624 \\
\hline
\end{tabular}

R2 AND DOCTORAL

\begin{tabular}{lccccc}
\hline & $(1)$ & $(2)$ & $(3)$ & $(4)$ & $(5)$ \\
& NT:0-30k & NT:30k-48k & NT:48k-75k & NT:75k-110k & NT:110k+ \\
\hline IS Tuition + Fees & $1.409^{* *}$ & $1.582^{* * *}$ & $1.815^{* * *}$ & $1.368^{* * *}$ & $.702^{* *}$ \\
& $.558)$ & $(.532)$ & $.439)$ & $(.389)$ & $(.312)$ \\
Median Inc x IS TF & -.016 & $-.018^{*}$ & $-.022^{* * *}$ & $-.016^{* *}$ & -.001 \\
& $(.011)$ & $(.01)$ & $(.008)$ & $(.007)$ & $(.004)$ \\
Observations & 890 & 890 & 888 & 881 & 872 \\
R-squared & .182 & .146 & .136 & .149 & .317 \\
\hline
\end{tabular}

NON-RESEARCH

\begin{tabular}{|c|c|c|c|c|c|}
\hline & $\begin{array}{c}(1) \\
\text { NT:0-30k }\end{array}$ & $\begin{array}{c}(2) \\
\text { NT:30k-48k }\end{array}$ & $\begin{array}{c}(3) \\
\text { NT:48k-75k }\end{array}$ & $\begin{array}{c}(4) \\
\text { NT:75k-110k }\end{array}$ & $\begin{array}{c}(5) \\
\text { NT:110k+ }\end{array}$ \\
\hline IS Tuition + Fees & $\begin{array}{c}1.156 * * * \\
(.206)\end{array}$ & $\begin{array}{c}1.482 * * * \\
(.216)\end{array}$ & $\begin{array}{c}1.695^{* * *} \\
(.237)\end{array}$ & $\begin{array}{c}1.34 * * * \\
(.229)\end{array}$ & $\begin{array}{c}.682 * * * \\
(.222)\end{array}$ \\
\hline Median Inc x IS TF & $\begin{array}{c}-.007 * * \\
(.003)\end{array}$ & $\begin{array}{c}-.012 * * * \\
(.003)\end{array}$ & $\begin{array}{c}-.014 * * * \\
(.004)\end{array}$ & $\begin{array}{l}-.007 * * \\
(.003)\end{array}$ & $\begin{array}{l}.003 \\
(.003)\end{array}$ \\
\hline $\begin{array}{l}\text { Observations } \\
\text { R-squared }\end{array}$ & $\begin{array}{r}2857 \\
.279 \\
\end{array}$ & $\begin{array}{r}2841 \\
.216 \\
\end{array}$ & $\begin{array}{r}2832 \\
.216 \\
\end{array}$ & $\begin{array}{l}2815 \\
.302 \\
\end{array}$ & $\begin{array}{c}2763 \\
.37\end{array}$ \\
\hline \multicolumn{6}{|c|}{ 2-YEAR INSTITUTION } \\
\hline & $\begin{array}{c}(1) \\
\text { NT:0-30k }\end{array}$ & $\begin{array}{c}(2) \\
\text { NT:30k-48k } \\
\end{array}$ & $\begin{array}{c}\text { (3) } \\
\text { NT:48k-75k } \\
\end{array}$ & $\begin{array}{c}(4) \\
\text { NT:75k-110k }\end{array}$ & $\begin{array}{c}(5) \\
\text { NT:110k+ }\end{array}$ \\
\hline IS Tuition + Fees & $\begin{array}{c}1.071 * * * \\
(.365)\end{array}$ & $\begin{array}{c}1.452^{* * * *} \\
(.43)\end{array}$ & $\begin{array}{c}1.189 * * * \\
(.293)\end{array}$ & $\begin{array}{c}1.234^{* * *} \\
(.331)\end{array}$ & $\begin{array}{l}1.6^{* * *} \\
(.359)\end{array}$ \\
\hline Median Inc $x$ IS TF & $\begin{array}{l}-.001 \\
(.005)\end{array}$ & $\begin{array}{l}-.007 \\
(.006)\end{array}$ & $\begin{array}{l}-.003 \\
(.004)\end{array}$ & $\begin{array}{l}-.004 \\
(.005)\end{array}$ & $\begin{array}{l}-.01^{*} \\
(.006)\end{array}$ \\
\hline $\begin{array}{l}\text { Observations } \\
\text { R-squared }\end{array}$ & $\begin{array}{l}3065 \\
.245 \\
\end{array}$ & $\begin{array}{l}3041 \\
.195 \\
\end{array}$ & $\begin{array}{c}3020 \\
.193 \\
\end{array}$ & $\begin{array}{r}2859 \\
.154 \\
\end{array}$ & $\begin{array}{r}2475 \\
.226 \\
\end{array}$ \\
\hline \multicolumn{6}{|c|}{ 4-YEAR INSTITUTION, TOTAL } \\
\hline & $\begin{array}{c}(1) \\
\text { NT:0-30k }\end{array}$ & $\begin{array}{c}(2) \\
\text { NT:30k-48k }\end{array}$ & $\begin{array}{c}(3) \\
\text { NT: } 48 \mathrm{k}-75 \mathrm{k}\end{array}$ & $\begin{array}{c}(4) \\
\text { NT:75k-110k }\end{array}$ & $\begin{array}{c}(5) \\
\text { NT:110k+ }\end{array}$ \\
\hline IS Tuition + Fees & $\begin{array}{c}.983 * * * \\
(.232)\end{array}$ & $\begin{array}{c}1.346^{* * * *} \\
(.171)\end{array}$ & $\begin{array}{c}1.688 * * * \\
(.191)\end{array}$ & $\begin{array}{c}1.565^{* * *} \\
(.202)\end{array}$ & $\begin{array}{c}.898 * * * \\
(.128)\end{array}$ \\
\hline Median Inc $x$ IS TF & $\begin{array}{l}-.01 * * * \\
(.004)\end{array}$ & $\begin{array}{c}-.015 * * * \\
(.003)\end{array}$ & $\begin{array}{c}-.021 * * * \\
(.003)\end{array}$ & $\begin{array}{c}-.018 * * * \\
(.004)\end{array}$ & $\begin{array}{l}-.003 \\
(.002)\end{array}$ \\
\hline Observations & 4426 & 4410 & 4399 & 4375 & 4314 \\
\hline R-squared & .187 & .166 & .18 & .189 & .428 \\
\hline
\end{tabular}

Note: The table shows selected coefficients from a regression of net tuition on in-state tuition and fees and an interaction of tuition and fees with median household income (in $\$ 1,000 \mathrm{~s}$ ). All regressions include year and university fixed effects, state-level unemployment rate, and high-school graduating cohort. The regressions are weighted by baseline enrollment. Standard errors are clustered at the university level. 
Appendix Table 3: Effects of Changes in State Appropriations on In-State Tuition and Fees, 2008-2017

$\underline{\mathrm{R} 1}$

\begin{tabular}{|c|c|c|c|c|c|c|}
\hline & $\begin{array}{c}(1) \\
\text { IS T+F }\end{array}$ & $\begin{array}{c}(2) \\
\text { IS T+F }\end{array}$ & $\begin{array}{c}(3) \\
\text { IS T+F }\end{array}$ & $\begin{array}{c}(4) \\
\text { IS T+F }\end{array}$ & $\begin{array}{c}(5) \\
\ln (\mathrm{IS} T+\mathrm{F})\end{array}$ & $\begin{array}{c}(6) \\
\ln (\mathrm{IS} T+\mathrm{F})\end{array}$ \\
\hline State Appr. $(1,000 \mathrm{~s})$ & $\begin{array}{c}.004 * * * \\
(.001)\end{array}$ & $\begin{array}{c}-.015^{* * *} \\
(.005)\end{array}$ & & & & \\
\hline State Appr./Student & & & $\begin{array}{c}-.126^{* * *} \\
(.045)\end{array}$ & $\begin{array}{c}-.504 * * * \\
(.158)\end{array}$ & & \\
\hline $\ln$ (State Appr.) & & & & & $\begin{array}{c}-.095^{* *} \\
(.04)\end{array}$ & $\begin{array}{c}-.285 * * * \\
(.093)\end{array}$ \\
\hline Observations & 718 & 718 & 718 & 718 & 718 & 718 \\
\hline R-squared & .71 & .586 & .7 & .588 & .706 & .657 \\
\hline First-Stage F & & 11.802 & & 17.617 & & 91.003 \\
\hline Model & OLS & IV & OLS & IV & OLS & IV \\
\hline
\end{tabular}

$\underline{\text { R2 AND DOCTORAL }}$

\begin{tabular}{|c|c|c|c|c|c|c|}
\hline & $\begin{array}{c}(1) \\
\text { IS T+F }\end{array}$ & $\begin{array}{c}(2) \\
\text { IS T+F }\end{array}$ & $\begin{array}{c}(3) \\
\text { IS T+F }\end{array}$ & $\begin{array}{c}(4) \\
\text { IS T+F }\end{array}$ & $\begin{array}{c}(5) \\
\ln (\mathrm{IS} \mathrm{T}+\mathrm{F})\end{array}$ & $\begin{array}{c}(6) \\
\ln (\mathrm{IS} \mathrm{T}+\mathrm{F})\end{array}$ \\
\hline State Appr. $(1,000 \mathrm{~s})$ & $\begin{array}{l}.004^{*} \\
(.002)\end{array}$ & $\begin{array}{c}-.013 * * * \\
(.004)\end{array}$ & & & & \\
\hline State Appr./Student & & & $\begin{array}{c}-.072 * * \\
(.033)\end{array}$ & $\begin{array}{c}-.415^{* * *} \\
(.106)\end{array}$ & & \\
\hline $\ln$ (State Appr.) & & & & & $\begin{array}{c}-.04 \\
(.031)\end{array}$ & $\begin{array}{c}-.311 * * * \\
(.078)\end{array}$ \\
\hline Observations & 1005 & 1005 & 1005 & 1005 & 1005 & 1005 \\
\hline R-squared & .679 & .636 & .68 & .529 & .683 & .517 \\
\hline First-Stage F & & 33.472 & & 54.366 & & 120.706 \\
\hline Model & OLS & IV & OLS & IV & OLS & IV \\
\hline
\end{tabular}

\section{NON-RESEARCH}

\begin{tabular}{|c|c|c|c|c|c|c|}
\hline & $\begin{array}{c}(1) \\
\text { IS T+F }\end{array}$ & $\begin{array}{c}(2) \\
\text { IS T+F }\end{array}$ & $\begin{array}{c}(3) \\
\text { IS T+F }\end{array}$ & $\begin{array}{c}(4) \\
\text { IS T+F }\end{array}$ & $\begin{array}{c}(5) \\
\ln (\mathrm{IS} \mathrm{T}+\mathrm{F})\end{array}$ & $\begin{array}{c}(6) \\
\ln (\mathrm{IS} T+F)\end{array}$ \\
\hline State Appr. $(1,000 \mathrm{~s})$ & $\begin{array}{c}-.003 * * \\
(.001)\end{array}$ & $\begin{array}{c}-.009 * * * \\
(.002)\end{array}$ & & & & \\
\hline State Appr./Student & & & $\begin{array}{c}-.038^{* *} \\
(.017)\end{array}$ & $\begin{array}{c}-.304 * * * \\
(.046)\end{array}$ & & \\
\hline $\ln$ (State Appr.) & & & & & $\begin{array}{l}-.024 \\
(.023)\end{array}$ & $\begin{array}{c}-.165 * * * \\
(.031)\end{array}$ \\
\hline Observations & 3459 & 3459 & 3459 & 3459 & 3459 & 3459 \\
\hline R-squared & .729 & .72 & .728 & .643 & .729 & .695 \\
\hline First-Stage F & & 160.527 & & 240.925 & & 454.295 \\
\hline Model & OLS & IV & OLS & IV & OLS & IV \\
\hline
\end{tabular}

Notes: All regressions include year and university fixed effects, state-level unemployment rate, and high-school graduating cohort size. The regressions are weighted by baseline enrollment. Standard errors are clustered at the university level. The instrument in the IV regressions is constructed from the state-level appropriations from the State Higher Education Executive Officers Association (SHEEO). The instrument is in levels, appropriations per high school graduate in the state, and logs, corresponding to the units of institutional appropriations in the second stage. 